Article

\title{
Project-Based Work and Sustainable Development-A Comparative Case Study of Cultural Animation Projects
}

\author{
Małgorzata Ćwikła ${ }^{1}$, Anna Góral ${ }^{1, *} \mathbb{1}$, Ewa Bogacz-Wojtanowska ${ }^{1}(\mathbb{C}$ and \\ Magdalena Dudkiewicz ${ }^{2}$ \\ 1 Faculty of Management and Social Communication, Jagiellonian University, 30-348 Cracow, Poland; \\ malgorzata.cwikla@uj.edu.pl (M.Ć.); ewa.bogacz-wojtanowska@uj.edu.pl (E.B.-W.) \\ 2 Institute of Applied Social Sciences, University of Warsaw, 00-927 Warsaw, Poland; madud@gazeta.pl \\ * Correspondence: anna.goral@uj.edu.pl
}

Received: 15 May 2020; Accepted: 10 August 2020; Published: 12 August 2020

check for updates

\begin{abstract}
Currently, a growing interest in the issues related to sustainable development can be observed, with the role of culture in stimulating this development increasing simultaneously. Nevertheless, the function and meanings of culture for sustainable development, as well as culture in the context of sustainable development, have so far remained under-emphasised and under-theorised. For this reason, in this paper we will look at practical examples of culture and sustainable development combined. The undertaken research problem explores the project-based work in the field of cultural animation, and its impact on the pursuit of the objectives of sustainable development at the local level. Two case studies of Polish organisations involved in cultural animation activities have been analysed herein. Based on the research results, we showed that cultural animation is an important tool for enabling local communities to achieve sustainable development. What is also important is the fact that cultural animation activities often take the form of project-based work, which significantly affects the methodology and extent of their implementation. Therefore, in this article we also point to the relationship between the management of animation projects and the idea of sustainable development, emphasising both advantages and disadvantages thereof.
\end{abstract}

Keywords: cultural animation; project-based work; sustainable development; cultural sustainability; local development

\section{Introduction}

Culture is an inseparable part of local development processes. On one hand, researchers of these links draw attention to the role of culture in building local communities through certain values and the sense of local identity built thereupon [1,2]. On the other hand, the role of culture in strengthening and developing local communities has also been emphasised [3-5]. This particular dimension of culture has been analysed by researchers due to both its social and economic aspects $[3,5,6]$. This way of perceiving the role of culture in local development processes leads to the concept of sustainable development, and for the purpose of this text it was decided to define this after the "Our Common Future" report, which specifies it as "development that meets the needs of the present without compromising the ability of future generations to meet their own needs" [7]. The most prominent example thereof is Bilbao in Spain, or Liverpool in the UK-the cities where cultural activity has become the main drive for growth. Activities related to cultural animation, often described also as both social and cultural, taken by various organisations, play an important role in these processes. For the purpose of this paper we understand culture after Spencer-Oatey as "a fuzzy set of basic assumptions and values, 
orientations to life, beliefs, policies, procedures and behavioural conventions that are shared by a group of people" [8].

The literature provides relatively extensive information on cultural animation and sustainable development. Researchers draw particular attention to the relationships between sustainable development and cultural policies [9]. Cultural animation is often combined with sustainable development understood as social and economic development of 'difficult' places [10,11], or so called place making [12]. The relationship between cultural institutions, cultural sustainability and cultural policies is also emphasised $[13,14]$. Moreover, researchers point to identifying and analysing various strategies that can be implemented in order to use culture to fulfil the general objectives of sustainable development $[15,16]$. The role of local communities in building sustainable development is particularly emphasised [17]. On the other hand, the effectiveness of practical tools used to empower communities to develop sustainably based on their cultural resources draws less attention, which can be understood as a research gap. Hence, one of the aims of our research was to fill this gap by focusing on how cultural animation projects are used to pursue the objectives of the idea of sustainable development at the local level.

Animation activities, for the purpose of this text defined after Trilla as "a set of actions delivered by individuals, groups or institutions in a community, and in a specific territory with the aim of promoting, among its members, an attitude of active participation on the process of their own social and cultural development" [18], are performed by organisations from the public sector and third sector (NGOs), as well as informal groups. They have different forms and different aims, depending on the space in which they are realised. These aims, as assumed by practitioners of animation, should reflect the context: the current needs of both the participants in animation activities, and-even more often so-the current directions of development, as indicated in public policies [19]. Hence, animation activities can refer to the current social problems, such as unemployment, marginalisation of social groups and environment protection, or they are aimed at boosting entrepreneurship among certain social groups. Thinking about the future is also important. Due to this current approach to cultural animation, they are often realised as projects-initiatives with strictly defined objectives, timeframes, budget, and assumed results to achieve [20]. This specific form of animation, often stemming from the available forms of financing (basically very transparent and precise), often seems unwilling and uncomfortable with the cultural and artistic activities that form the project. This is because indicators such as time, budget, results, or precise objectives are more limiting than liberating in the area of arts and emancipation. The shape of these indicators often results not from the real needs of local communities, but the provisions of public policies, or expectations of sponsors or funders [21]. Researchers emphasise that project, as a form of task realisation, tends to enable more flexibility in action, promising the realisation of new, non-standard objectives and making it possible to easily verify their effectiveness. On the other hand, its formula is sometimes regarded as oppressive [22]. Researchers even express their accusations that the anticipation of results typical for projects is contradictory to the process of discovery [23], and similar assumptions are possible for animation projects. Therefore, the specifics of project activities in the area of cultural animation provoke reflection on their impact on the sustainable development of the communities they refer to. This is because-at the first glance-the assumptions of time-limited project work seem incompatible with the logic of sustainable development, defined as "development that meets the needs of the present without compromising the ability of future generations to meet their own needs" [7]. The definition broadly refers to global and intragenerational equity, and fairness in the distribution of welfare, utilities, and resources between generations [24]. One of the most important features of sustainable development is the realisation of long-term goals towards the satisfaction of the complex needs of the community it refers to. However, the practice of managing local development has made numerous attempts to achieve sustainable development through projects, as proved by public policies and the tools used for their realisation, such as the implemented financial and project-based mechanisms. Simultaneously, practitioners and theoreticians of management see the necessity of taking interest in sustainable development [25-28]. Moreover, 
the process-based approach to projects is becoming more popular, which may indicate the necessity of looking at project management as a managerial practice aimed at development irrespective of the project framework defined [29].

For this very reason, considering the wide interest in sustainable development, both among scientists and politicians or practitioners of local development, and also taking into account the growing role of cultural activities in stimulating this development, we decided to verify how project-based practices in the area of cultural animation influence the endeavour to realise the assumptions of sustainable development at the local level. Therefore, we analysed two case studies of organisations involved in cultural animation activities.

By examining the implementation of the concept of sustainable development through cultural animation at the local level, the overall aim of the paper is to increase the understanding of the role of cultural animation in sustainable development.

We would like to begin with clarification of the theoretical background of the research in order to explain how we see the role of culture in sustainable development and cultural animation, as well as its current specifics and contexts, and discuss how it is being implemented in local communities, paying special attention to the project-based work in the field of culture, and the relation between project management and sustainable development. We will then describe the method and the data. In the main part of the article, we will present two case studies and discuss the implications of the results for research and sustainable development at the local level.

\section{Theoretical Background}

\subsection{Cultural Animation Aimed at Sustainable Development}

The notion of sustainable development is now established and significant in the scientific discourses of both management and local development studies. As emphasised by Swanson and DeVereaux [30], its foundations are based on four pillars: economy, society, environment and culture. It should also be noticed that the role of culture in sustainable development was the last to be acknowledged. Early pioneers of the so called 'cultural sustainability' paradigm in the 1990s defined the need to strengthen the interrelationship between culture and development as crucial for local sustainability [24,31,32]. Loach, Rowley and Griffiths [14] write that "culture is essential for a sustainable society to be possible". Soini and Dessein [33] regard culture as an "overarching dimension of sustainability", which encloses the other three pillars of sustainability and leads to development as a cultural process. This stems from the conviction that in order to co-create the space around us in a conscious and responsible way, one has to share certain beliefs, values, practices and visions of the future of the society one is part of [34]. The notion of cultural sustainability was first defined, by the World Commission on Culture and Development, as inter- and intra-generational access to cultural resources [24]. Pop, Borza, Buiga, Ighian and Toader [16], following Mpofu [35], emphasise that "cultural sustainability also implies that development takes place in a way that respects the cultural capital and values of society". In this particular manner, the researchers emphasised the role of culture in local planning. The cultural dimension of sustainability was also discussed by Chiu [36], who linked it to development of housing, Nurse [1] or Asikainen et al. [37], who studied the culture of sustainable development, Birkeland [10], who in her research studied the role of cultural resources in the regeneration of postindustrial areas, and Hristova, Dragisevic-Sesic and Duxbury [38] who focused on various cultural models of sustainable development implemented by European cities. The considerations of both the researchers and practitioners of sustainable development concerning the role of culture in sustainable development emphasise also such issues as intergenerational solidarity [35], caring about common values [39], and the role of emancipation in building sustainable development [40]. The above-mentioned researchers explored particularly the subject of cultural sustainability from a social point of view. The topic from a cultural economy point of view was discussed by Throsby [3,41], and also from a community development perspective, as by Duxbury and Gillette [42]. However, Throsby [41], as well as Soini and 
Birkeland, note that "the role and meanings of culture in sustainable development, and culture in the framework of sustainable development has remained under-emphasised and under-theorised" [24]. As recently noted by Pop, Borza, Buiga, Ighian and Toader [16], as the concept of cultural sustainability began to develop, the general attention focused on identifying and analysing the practical tools and ways through which culture could be preserved, controlled and modelled in such a way that the general objectives of sustainable development are fulfilled. The characteristics of culture combined with sustainable development can be found in numerous bottom-up initiatives realised at the local level by and for local communities [43] as part of the so-called cultural animation.

Animation as a specific social and cultural phenomenon received its name and developed in the first half of the 20th century, gradually gaining substantive popularity with practitioners of local development, mainly in culture [44]. Its roots can be found in the development of the processes of the democratisation of societies and the intention to actively involve citizens in the development of the space they co-create [45]. As emphasised by researchers, defining cultural animation has been a challenge for many theoreticians and practitioners $[43,46,47]$. Montez underlined that cultural animation (or as he calls it, sociocultural animation) is a broad scope of social practices, and definitions of its concept stem from multiple experiences and visions [48]. Gillet claims that cultural animation is one of the "unfindable definitions" as, depending on the angle taken, the researchers define it in many different ways [49]. The definition of cultural animation is often used to categorise a whole group of practices and activities delivered by people to and performed with other people. One of the first, proposed by the Council of Europe, explains animation as a methodology used to provoke changes in the behaviours of people and their collectives, which can be used towards a diverse range of goals [50]. Other researchers writing about cultural animation often take different perspectives and discuss the ideas of cultural animation as an action, a social practice, method, technique, tool, process, programme, social function or factor [51,52]. James [45] draws attention to the fact that animation, regardless of the adjective that specifies it, is a way of navigating through the social reality. Morawska and Latoc-Zielińska [53] show in their research that cultural animation is simultaneously an idea, a number of specific initiatives and actions, a method and a strategy of acting, a particular way of participating in culture, and even a kind of a social movement. For the sake of an introductory representation of those approaches, it is worthwhile to claim that cultural animation is firstly a "direction of action among people and with people"; secondly, "a method of action based on stimulation"; and thirdly, "a process of self-discovery" [46]. For the sake of the deliberations that constitute the basis of this text, and hence in order to understand the phenomenon of animation and its role in the development of local communities, it was important as the starting point to use the constructivist perspective to look to what the vision of the human being in the society undergoing cultural animation is. This perspective of the animation-oriented approach casts the man as both a creator and receiver of social and cultural action, who, in spite of their (symbolic and real) anchoring in the community, remains autonomic. It implies the need to be open to and accept otherness and difference. As Barbara Fatyga underlines, "cultural animation (...) refers to a specific way of acting by the animator within the living culture of certain groups or communities. The animation-oriented way of influencing the cultural reality is primarily linked to the animator spotting various types of deficits in the life of these groups or communities (...) Based on the joint decision of the animator and the people among whom the former works, the deficits found become deemed possible to remove with the use of various cultural tools. For this reason, cultural animation does NOT equal publicising culture, much less popularisation there of or cultural education, (although animation may include such elements). Cultural animation in a group or community requires a reliable diagnosis of deficits, deliberate methods of acting based on the idea of releasing and supporting local resources and-most often-long-term involvement aimed at triggering and consolidating change" [54]. The vision of the man in the animation approach assumes active, yet fully consensual and all-available, participation not possible outside of the other important ideological context of animation activities in culture, that is, the democratic system. The most important component here is civil society. While explaining the idea of civil society, the unprompted, 
voluntary networks of relationships and actions between people who express their ideas, passions and interests, or realise common objectives, are emphasised [55,56]. Andrzej Sicinski [57] also described it through three basic dimensions: a horizontal (in opposition to vertical) organisation of the society; a participatory society in opposition to a "reclusive" one; an open society in opposition to a closed one. Furthermore, the pro-animation qualities of a civil society include the following: being anchored in a community, readiness to take action for the sake of the common good, and the ability to self-organise independently of an external (especially state-level and institutional) formal impulse. In a democratic system, self-organisation is understood not as an activity that happens against the state, but rather on the level of partnership, or alongside it [58]. Animation activities help to establish contacts and social relations, to understand and get to know the world (also the world of artistic activity), often through bringing them down to the context of the closest surroundings of a person. The above considerations on the ideological background of cultural animation can be best summed up following Andrzej Mencwel, who stated that "we are guided by the idea of cultural personality realising itself actively in the immediate, human surroundings." [59].

To sum up, we can say that among the key characteristic features of cultural animation, researchers emphasise its pro-social character given it relation to the actions directed at shaping the community and fighting isolation and exclusions, which are often taken in disintegrated communities (e.g., artificially created in a new place, or immigrant-based) [45], which focus on participation and self-expression through calling on the democratic ideals of culture and enhancing civic consciousness, which have as their aim cooperation between individuals, which is to lead to, among others, creating places of informal meetings and the more complete use of institutional infrastructure, which becomes somewhat "socialised" in this process [60]. Simultaneously, researchers underline that animation activities are based on direct intervention (often by the exertion of external forces) directed towards liberation and emancipation, and gaining (or regaining) the sense of agency, self-determination and control over one's own fate. Actions taken in this direction often have a political context, and are treated as a danger to the extant status quo [47]. Such an approach to animation enables the linking of it to the idea of sustainable development, especially in its cultural dimension, treating it as a tool supporting its implementation at the local level $[19,53]$, as by reaching to local cultural resources and engaging the local community in the process of change and the solving of its problems, animation activities have an influence on shaping group awareness and understanding of the idea of sustainable development and care for the space that this community co-creates. This is important since the more widely known and used tools for sustainable development, such as life cycle assessment (LCA), ecological footprint (EF) and Factor $\mathrm{X}$, are incomprehensible for local communities, who thus disregard them in their everyday activity [61].

\subsection{Project Management and Sustainable Development}

Project management has accompanied humanity since the ancient times. As an organisational practice it occurred in the 1930s, and was systematised in the 1950s [62]. The original context of the codified procedures was formed by activities related to the space and arms industry, including the Polaris project, the projects at NASA [63] and the Marshall plan. In the next decades, project management was gaining popularity, and projects started to be realised in various areas, first in organising large construction enterprises, then also in the IT industry and manufacturing, and since the 1990s, it has been present in all kinds of organisations, including non-profit ones [64]. Understanding enterprises through project logic, both in operations and the language used, became a common solution (currently the word "project" is not a technical term, but an element of the universal language). The basis of project management is to precisely define objectives, the demand for resources and the range and criterion of quality, as well as to follow certain steps (definition, planning, realisation, control and the final evaluation). Projects can also be regarded as opposed to improvisation [62], which does not diminish their creative and exploratory character. As a result of projects gaining popularity, methodologies of conduct were developed. These include PERT (1958), Scrum (1986), PMBOK (1996) 
and PRINCE2 (1996), which today form guidelines in project management. There are also alternative views, in the area of critical studies, in which projects are supposed to serve not only as a tool to generate profit, but also as frameworks for empathic studies and solidarity [22]. Projects currently play an important role on many levels of the functioning of societies, shaping not only day-to-day organisation, but also public policies and the fate of individuals. Moreover, project management is an important subdiscipline of management science, developed intensively from the mid-1990s [62]. The cases described in the literature on this subject document the significance of projects in practical reality, underlining the anchoring thereof in the contemporary social and economic conditions. For example, Turner with co-authors calculated that one third of the global GDP is generated by projects [65], Lundin and co-authors prove that after agricultural and industrial societies came the project society, which can be understood as a synonym for "Information," "Knowledge," or "Network" Society [66]. In this way, they introduced the discussion of projects into the current scientific debate about contemporary society, and the changes that affect us all. Jensen and co-authors in turn write about "projectification of everything", including individual behaviours of a non-professional nature [67]. Hence, project management currently forms a significant context for the other studies undertaken by organisations in order to react to the surrounding requirements. Recognising this, and considering the popularity of projects, it is worth highlighting their original meaning. In terms of etymology, the word project comes from Latin and means "something thrown forward" [68]. Thus, it is a tool of change and the creation of new conditions in the future. Simultaneously, it symbolises the ability to create plans, identify problems and search for ways to solve them, the willingness to improve existing living conditions and familiarise with the unknown, which is only hidden in what is to come, and not experienced in the past. Project is simultaneously a process of transforming an idea into an object or a solution of a non-material nature. The aspect of changing the current conditions and creating solutions which are supposed to function in the future is linked to sustainable development. As stated in the above-mentioned popular definition of sustainable development, it is development that meets the needs of the present without compromising the ability of future generations to meet their own needs [7]. Therefore, both project management and sustainable development concern something that is yet to come. The former refers, to a larger extent, to reaction to the current demand, whereas the latter wants to prevent this reaction from becoming a burden for the next generations. It is not difficult to observe that the history of thought on sustainable development coincided with projects becoming more common in management in the second half of the 20th century. After the establishment of the World Commission on Environment and Development in 1983, the above-mentioned concept of "Our Common Future" was published, and in 1992 the Earth Summit took place in Rio, during which the principles setting the direction for social and economic activities were prepared, with environmental protection taken into account. In 2001, the first sustainable development strategy at the European Union level was devised. Together with new member states, the project mechanism of the EU was developing towards building structural funds, which offers an important insight concerning the two phenomena discussed herein, as it can be assumed that at the European Union level it is projects that should form the tools for implementing the assumptions related to sustainable development. Further, as noticed by researchers, the mechanisms of the EU essentially come down to project management [69].

For particular organisations, the idea of sustainable development influenced the development of organisational strategies, prompting companies to prepare their own concepts of Corporate Social Responsibility and Corporate Sustainability, some of which are also of project nature, occasionally related to shaping the image of businesses, and to marketing. At the moment, sustainable development is regarded as one of the paradigms of project management, including economic, ecologic and social threads [70]. Another important criterion is to recognise the difference between sustainable development as a process extended over some time, and the temporariness of projects which do not last long as a rule. For this reason, for a long time a lack of consistency between project management and sustainable development was observed, as mentioned in the introduction. This can be solved by regarding every project as an element building the strategy of sustainable development, which 
means taking responsibility even for micro-actions, and locating them in a wider context, particularly in the attempts to design the future. The already mentioned question of responsibility requires a critical vigilance in observing the popularity of projects, their unclear meaning, and the influence of large-scale project work on organisations and individuals. Their ubiquity can disturb sustainable development due to visible excessive activities limited in time, and lacking continuation or care for achieving results [67]. This poses the risk of missing harmony between "needs" and "limitations", so important for the idea of sustainable development. Hence, it is crucial to follow the development of the subdiscipline of project management with the project's reality in practical activity. In a holistic approach that is key to the contemporary understanding of projects [71], it is important to recognise the potential of conscious deprojectification [72], as well as the concept of "degrowth" [73] and the creation of value through projects [74]. However, at the project level, it is important to remember the perspective of stakeholders as long-term beneficiaries of project activities [75], and initiate discussions related to project ecology understood in two ways: as a network of interrelated activities, and the actual influence of projects on the environment, including a rational use of resources.

\section{Materials and Methods}

\subsection{Research Questions}

In order to give answers to the research problem (how project practices in the area of cultural animation influence the quest for the realisation of the assumptions of sustainable development at the local level), we have formulated three main research questions:

RQ1: How is cultural animation aimed at sustainable development carried out in local communities?

RQ2: What is the influence of project-based animation activities on sustainable development, and how do they contribute to building a sustainable ecosystem at the local level?

RQ3: How does project-based cultural animation, aimed at sustainable development, look in practice?

For the subject of our research we have chosen organisational practices in the projects realised, undertaken by organisations in the area of cultural animation with the aim of following the idea of sustainable development at the local level. For our research we have selected two types of organisations and practices-non-government and public-where the realisation of animation activities is most visible and has funds obtained from various programmes [76,77].

\subsection{Research Methods}

We selected the method of comparative case study [78,79], with the research area comprising two organisations (public and non-government) concerned with realising cultural animation projects in the area of sustainable development in two Polish towns. The cases have been selected as follows:

1. We chose two organisations conducting cultural animation projects in the area of sustainable development in two small towns. Animation activity in small towns is usually run by one or two organisations and can be studied thoroughly, simultaneously getting to know the social and cultural context. In other words, they constitute a certain lens for animation activities which can easily be observed, as opposed to large cities where animation activities, projects and practices are multidimensional and versatile.

2. We selected organisations with the first being a public one realising social and cultural animation objectives determined by the state, and the other being a non-government organisation with autonomous (regardless of the state) animation objectives set by the founders of the organisation. Both NGOs and public organisations undertake cultural animation activities in Poland, though usually using different methods.

3. Simultaneously, despite the contrasting forms and organisational aims and methods of the selected cases, both were similar to each other in terms of how they approached cultural animation as an 
activity benefiting sustainable development. Thus, they were selected as both contrasting and to some extent similar.

4. The selection was also due to the research experience of the authors-the research material previously collected during the many years of observing cultural animation and project realisation. Between 2010 and 2020 we realised in-depth studies, in 20 local/community organisations in Poland, of projects and social and cultural animation. Therefore, the fact that these two have been selected did not stem from a mere reading of project names, but from noticing in both of them particular features that bring their cultural project activities into a wider context of sustainable development.

5. Last but not least, we selected two cases with one finishing with a failure and the other with success.

A comparative case study is a variant of a multiple case study. During its realisation, researchers focus on getting to know the studied phenomenon and the influence of the social, political, economic and cultural context on its character and shape [80]. An instrumental case study was chosen and can be understood as the study of a case (e.g., person, specific group, occupation, department, organisation) in order to provide insight into a particular issue, redraw generalisations, or build theory [80]. The instrumental case study also allows one to examine both the case and its context, while interest in case is not the purpose of the study, but is to be "supportive and facilitates understanding of something else" [78]. Therefore, we expected to extend knowledge and to clarify some generalisations about project practices in the area of cultural animation, where sustainable development concepts are realised in practice.

For each case study a qualitative procedure was applied. The following research methods were selected: interviews with representatives of the organisations, analysis of the documents of a given organisation, and observation [81,82].

\subsection{Research Process}

The research process was conducted as follows. The cases were studied sequentially [83]. After realisation of the studies for case 1 (Animation 1-public organisation) and analysis of the results, we began to study case 2 (Animation 2-NGO). For case 1 (Animation 1 ) the range of the data collected was much larger; the two case studies were conducted in a different time and a different context of their functioning. These time and context differences were intended to extend our understanding and the interpretation of projects and cultural animation towards sustainable development. It also needs to be emphasised that case 1 finished with a failure, and so case 2 was supposed to enable the collection of data from a successful case of cultural animation activities. The stages of the research process and the selection of the methods remained the same, while the organisational situations of the cases during our study were different.

For each case the first stage of the research process was to gain a deep understanding of the historical, cultural, economic and social context, as a given case constitutes "a composite whole situated in a certain surrounding, environment, and rooted in many contexts" [80]. This stage comprised a study of external documents (related to the context of the case study, the organisation/community), an analysis of the websites (of the animation projects) and a study visit and observation of animation practices. The second stage consisted of interviews in the studied organisations/communities; individual interviews in the first case, and group and individual interviews with representatives of organisations and participants of animation projects in the second. In this phase observation of animation practices was also carried out. The third phase involved a study of the documents of the organisation and those concerning the projects realised by the organisation, as well as more observation of animation practices.

Table 1 presents in detail the research techniques, the number of the conducted observations, interviews, and analysed documents, as well as the time of research realisation. 
Table 1. Research techniques used during the studies.

\begin{tabular}{|c|c|c|}
\hline & $\begin{array}{c}\text { Animation 1-Social Service } \\
\text { Centre }\end{array}$ & Animation 2-Association \\
\hline Date of the study & 2010-2013, 2017 & 2017-2019 \\
\hline $\begin{array}{l}\text { Observation of animation } \\
\text { practices—study visits }\end{array}$ & $\begin{array}{l}3 \text { study visits in the studied } \\
\text { community/organisation realising } \\
\text { animation (approx. every } \\
3-4 \text { months). Duration of each } \\
\text { visit-around } 3 \text { days }\end{array}$ & $\begin{array}{l}2 \text { study visits in the studied } \\
\text { community/organisation realising } \\
\text { animation (approx. every } 4 \text { months). } \\
\text { Duration of each visit-1 day }\end{array}$ \\
\hline $\begin{array}{c}\text { Analysis of the organisation } \\
\text { documents }\end{array}$ & 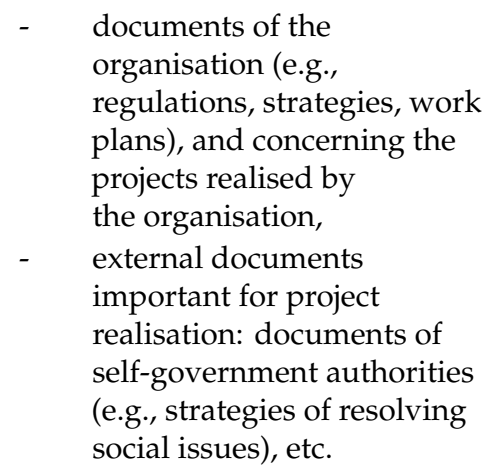 & $\begin{array}{l}\text { - documents of the organisation } \\
\text { (e.g., the charter) and concerning } \\
\text { the projects realised by } \\
\text { the organisation, } \\
\text { external documents important } \\
\text { for project realisation: } \\
\text { documents of self-government } \\
\text { authorities (e.g., strategies of } \\
\text { resolving social issues), etc. } \\
\text { - websites and social media }\end{array}$ \\
\hline In-depth interviews & $\begin{array}{l}\text { - } 8 \text { individual open interviews } \\
\text { with people from the } \\
\text { organisation and its } \\
\text { surroundings who are key } \\
\text { for the project }\end{array}$ & $\begin{array}{l}3 \text { interviews with representatives of } \\
\text { the organisation, } \\
2 \text { focus interviews with participants of } \\
\text { animation projects }\end{array}$ \\
\hline
\end{tabular}

Source: Own work.

\subsection{Data Analysis, Interpretation and Presentation}

We performed analysis and interpretation during the whole study period, separately for the first case and then comparatively for the second. The process of data collection and analysis was tedious for each case ( 3 years), and was used for systematically collecting and organising the data, then for carrying out initial interpretation thereof in order to search for further useful information. As written by Holstein and Gubrium [84], "interpretative practice engages both the hows and the whats of social reality; it is centred in both how people methodically construct their experiences and their worlds, and in the configurations of meaning and institutional life that inform and shape their reality-constituting activity".

The interpretive paradigm [85] and social constructivism [86,87] together constitute an approach close to ours that attempts to show how we understand the world and the meanings given by people in an organisation. This means that we perceive the organisation "from the angle of social processes related to giving and reading meanings" [88], and these meanings are "socially or historically conditioned" [89].

Data analysis procedure:

- For each case, separate compilations of all the empirical data collected were prepared with the use of particular research techniques. Transcription of all interviews was performed, and all notes from observations during study visits, as well as both organisational and external documents, were compiled;

- The whole research material collected was preliminarily ordered for each case according to the following analytical criteria: (a) approach to sustainable development, (b) approach to animation, (c) comparison of the two animation projects to other activities of the organisations, (d) sustainability of animation activities constituting part of the project; 
- Tables with the above criteria were prepared. For each analytical criterion descriptive categories (main codes) were created, consisting of quotations from the interviews, comments from the observations and quotations from the documents. They were created based on many readings of the collected research material. For each descriptive category it was assumed that it has to be based on data stemming from at least two research techniques. Additionally, descriptive categories were prepared independently by two researchers. Thus, for the descriptive categories prepared, data triangulation and researcher triangulation were secured. This was aimed at increasing the interpretative possibilities of the research material acquired. The triangulations applied allowed us to increase the reliability of the ensuing descriptive categories, and provided the possibility to extend interpretation. Accordingly, we did not search for a picture of one reality, but for better understanding thereof $[90,91]$. The process of combining data within descriptive categories is presented in Graph 1 (Graph 1: The process of combining data within descriptive categories).

The interpretation of the data consisted of the following steps:

- After putting order to and understanding the research material in the form of criteria and descriptive categories, for each case studied we performed a synthetisation of the whole, and depicted project practices in the field of cultural animation and their influence on the realisation of sustainable development assumptions at the local level, in each case studied. This depiction facilitated all analytical criteria, immersed in various contexts, considering also the passing of time and theoretical threads.

- The final element of the interpretation was to prepare and write a coherent narration for each case studied.

- At the end we secured the anonymity of the organisations and the interviewees, and also anonymised the organisations' documents and interviewees' contributions. The first research case was marked as Animation 1, and the second as Animation 2. Therefore, the cited interview quotes are marked in the text as: A1-I/interview number, A2-I/interview number or A2-F/focus group interview number, from documents $\mathrm{A} 1-\mathrm{D} /$ document number or $\mathrm{A} 2-\mathrm{D} /$ document number, and notes from observation A1-O or A2-O.

\subsection{Limitations of the Study}

The first limitation was the need to select the research approach and the method of comparative case study, as drawing conclusions can be influenced by certain (though paradigmatically assumed) factors. First of all, the way of collecting data, including selection of the time and place, as well as the decision to focus on a specific aspect of a case, holds us as researchers responsible for the reliability of the way the results are presented. By adopting the interpretative-symbolic paradigm, we need to assume that all the collected and analysed data is part of someone's experience and a theoretical reflection of a researcher. The second limitation is of a geographical nature, as we studied cultural animation in Poland only. Simultaneously, it needs to be noticed that animation activities take place in many countries around the world, and there are many common features in this sort of activity, although in each country there are specific legal, social and organisational conditions limiting such comparison.

\section{Results}

In this part of the text, the explored cases will be presented. The analysis shall start with a short introduction of each case study. The description of each case consists of a few parts, i.e., the approach to sustainable development, the approach to animation, a description of the animation project studied, and the location of the project studied in the activities of the organisation. 


\section{1. "Animation 1" Case Study}

\subsubsection{Description of the Organisation}

The organisation performing social and cultural animation was the Municipal Social Service Centre (Polish: Miejski Ośrodek Pomocy Społecznej (MOPS)) in a small town in the north of Poland. The centre is a public organisation, and realises the tasks which were defined in detail in the legal provisions regulating the functioning of such organisations. Municipal Social Service Centres constitute a basic link in the social service system in Poland, with the tasks comprising inter alia support for individuals and families in surmounting a difficult life situation, integration with the socially excluded, creating social networks adequate to the needs in this area, and reducing cultural exclusion through activities aimed at increasing the accessibility of culture and arts. During the study the social service workers of the centre realised a project aimed at testing the model of Local Community Organisation, that is, activation of the project community and an attempt to reintegrate them with the society.

The animation project constituted part of the wider strategy of the studied organisation, and was directly related to its main objectives. Its realisation, thanks to the funds acquired for this purpose, allowed the strengthening of the activities realised by the organisation so far, and the enriching of their offer. The project made it possible for the organisation to achieve faster the objectives set in the area comprised of the project.

\subsubsection{Approach to Sustainable Development}

The way in which the studied organisation thinks about sustainable development is strictly related to the development strategy of the town it is located in. It is connected with the current development directions and the social-economic enterprises undertaken in the environment of the organisation. The aim of the organisation is to endeavour to support the community in which it is active, facing the changes happening in its surroundings and counteracting exclusion of the members of this community. Hence, sustainable development is a constant, long-term objective of the organisation. The activities undertaken were compliant with the idea of living culture, understood as the "multidimensional living environment of individuals and social groups and the functioning of social institutions, with dynamic processes taking place, cultural practices developing, and more or less sustainable results of the practices occurring (material and non-material creations)" [92]. Such an approach corresponds well with the idea of sustainable development, and activities aimed at increasing the quality of life of the disadvantaged communities are an important part of the cultural development of their members.

\subsubsection{Approach to Animation}

Cultural animation consisted here of the actions of animators in the area of the living culture of a specific community. In their activity in a given community, animators used the definition by which cultural animation is a notion of strong axiological markedness. It refers to the animator's specific way of acting in the area of the living culture of certain groups or communities. The animating way of influencing cultural reality is linked primarily to the animator noticing various types of deficits in the life of these groups or communities, and here is where valuating occurs in the form of certain ideals or even ideologies, concerning beliefs about man, desirable means of enabling the functioning of the society and the realisation of its objectives, etc. By the joint decision of the animator and the people among whom he acts, the deficits identified become considered possible to remove with the use of various cultural tools. For this reason, cultural animation is not identical to the universalisation of culture, let alone its popularisation or cultural education, although animation may include such elements [54,92].

Due to the definition adopted, the animating way of influencing cultural reality was primarily linked to animators identifying various deficits in the life of this municipal community. Hence, animation was understood as a social component of cultural phenomena, and as a category of change aimed at limiting the identified deficits of a certain community. Importantly, such an (mostly utilitarian) 
approach to culture (treated as an obvious surrounding for social practices and not an idealised theoretical construct) also made it possible to introduce in local communities important changes leading to their sustainable development.

The basic analytical category of the animation project studied was social change evoked by the intervention that was realised by the centre and was following a certain plan. It was understood not as a specific, clearly defined and possible-to-observe moment, but a long-term and complex social process. The project studied was part of a wider, long-term venture realised by the centre, aimed at supporting the local community and counteracting its exclusion, as the animation project was supposed to strengthen the interventions already conducted by the organisation. The social service workers knew that this could not be a single action, that they need to include their activities in the logic of the institution, and the institution needs to adjust as well [A1-I1].

\subsubsection{Animation Project}

The activities of the project studied were dedicated to a small community living in two old buildings-social housing barracks with electric heating, which generated very high costs for the users. The buildings were situated on the outskirts of the town, forming a kind of an island among fenced houses and blocks of flats. The occupants of the barracks formed a ghetto of the poor in the middle of an area of the wealthy; and they were an isolated group in their environment, making no external contacts and expecting no such contact from their neighbours. The community living in the barracks consisted of six usually large families-altogether over 30 people, including children. All of them were placed there for not paying the rent before. The families living there were usually affected by a complex combination of various pathologies and deficits-alcoholism, unemployment, health problems, sometimes violence. The occupants of the buildings did not form an integrated community; on a day-to-day basis, each family lived their own life.

Social workers realised the project in cooperation with many local institutions, both social care ones and self-government ones. The actions were managed by the organisers of local communities, and were dedicated to the project community, aimed at building a coalition of institutions to support the community. The activities started with meetings of potential partners, due to which a group of institutional entities and people eager to really get involved emerged: Many municipal institutions saw a chance to really change this "difficult place" [A1-I2]. It turned out to be possible to work out sustainable relations between institutions, and build a network consisting of many different entities able to cooperate as partners both formally and informally. A public meeting was organised for the project community, and finished with the priority need defined, i.e., insulation of the buildings. The acceptance of the votes of the inhabitants and respecting them, as one of the main assumptions of the personal animation approach, turned out to be apparently crucial for the success of the whole project. The animators simply realised that nothing concerning them should be discussed without them" [A1-I2]. Almost all inhabitants became involved in the work, which changed their attitude to each other, and gave them the feeling of agency and responsibility for their environment.

In the following months the inhabitants started to take actions themselves, without external instigation: they organised a Christmas Eve meeting, an Easter meeting, and plastered and painted the barracks on their own. Alongside the renovation works, actions were taken to organise, for two weeks during the summer school break, a summer play centre in the form of a thematic village in the area between the barracks, for all children from this settlement. This initiative can be considered especially important in the context of cultural animation. Together with the inhabitants (thus fully respecting their involvement and decision making), the activities of the summer play centre were co-organised by external partners: by instructors of arts (dance, singing, fine arts), organisers of sightseeing tours, and by visits from cultural institutions. The most important idea of such a location for these activities concerned the occupants of the barracks playing the role of hosts in the project (cleaning the area, preparing meals, watching over the children during trips, etc.), the aim of which was to change the way they look at this place-from "doomed" to "attractive". All activities were 
financed via self-government funds, including the budget from the Social Service Centre (a local activity programme), and at the cost of the urban property board.

\subsubsection{Continuity of Actions}

The main results of the project analysed include the improvement of the living conditions of the occupants of the barracks, the reduction of the costs of living, and the raising of the standard and improving the aesthetics of the apartments-the barracks now do not differ so much from their surroundings, and hence their appearance is not so stigmatising. This was symbolic for how the community started to be perceived in the whole town, as it suddenly turned out that this place can be safe and friendly too [A1-I1]. Another important thing was the changes in the whole "social tissue", and the quality of the relationships between the community and its direct vicinity. A framework of a new social order was created based on acting, responsibility for one's environment, and reciprocity. The apathy and passive waiting for help were overcome, and a new faith in their own (community) possibilities occurred, together with a growing feeling of agency. The success in running errands and organising various activities showed the inhabitants that co-action brings benefits, and that external institutions are not always hostile towards them. The third project result concerned the relationships with the immediate surroundings improving, mostly with the settlement of detached houses, as the inhabitants of the blocks of flats still keep aloof from the activities of the project community [A1-O4]. The relationships between the settlement and the barracks became more direct and open, and the occupants of the latter became more accountable for their environment, showing themselves from another side, meaning their social image changed: Joint activities brought people together, as it turned out that they need each other, that they are not so far from each other, also in cultural terms [A1-I4].

In the end, as proven by the last study visit, the project was not successful in the long run. This, though, was not due to a wrong method of cultural animation, but due to the ill ambitions of the local authorities that started to feel endangered by the growing position and authority of the person managing the Social Service Centre among the inhabitants. As a result, under the false pretences of a non-culpable mistake, this person was ousted. As a consequence, the whole work performed by the social care workers was wasted, and the project community was scattered in many random locations. However, it has to be added that they have realised the animation ideas in other communities.

\section{2. "Animation 2" Case Study}

\subsubsection{Description of the Organisation}

The second organisation studied was an association established in 2016, a local non-government organisation in a small town in the centre of Poland. The aim of the organisation is to initiate, support and organise various projects towards sustainable development of the local community, including in the following areas: civil society, culture, art, protection of cultural and national heritage and tradition, local identity and environment protection [A2-D1].

The association brings together a group of inhabitants and friends of the town that want to make the town more liveable. All actions of the association are driven by the conviction that people are the largest resource of the local community, while the activity and involvement of inhabitants are the main driving force of local development. Development is about change, and change is a process, which means many small and interrelated actions. By chasing change, we often run against the grain: We come back to the origins, we search for the roots, we rebuild the local community and do not allow discouragement or passiveness to win. We initiate, inspire, support, organise, change and act ... development is what individuals and social groups do, and not something that is done for them [A2-D2].

\subsubsection{Approach to Sustainable Development}

The approach of the organisation to sustainable development is built on the current lack of ideas for change or new directions of social or economic development in the town, together with years 
of relatively high unemployment and the difficult economic situation of the town and its residents. The association endeavours to initiate, support and organise various sustainable development projects in the following areas: civil society, entrepreneurship, including social entrepreneurship, culture, art, protection of cultural heritage and tradition, local identity, science, education, ecology and animal protection, and protection of the natural heritage, health protection and prevention, tourism and sightseeing, revitalisation [A2-D3].

The approach of the organisation to the sustainable development of the local town is also based on two pillars: providing support for development of the areas regarded as underdeveloped, as well as supporting the efforts of public organisations (the town hall and subordinate offices) aimed at modernising the town. The establishment of the organisation was supposed to extend the possibilities of launching new activities, actions and projects, which-due to their objectives—cannot be realised by the public sector. Moreover, it is also crucial that the association is regarded primarily as a social activity of the town dwellers and their involvement in social issues, though this requires some drive, support and facilitation.

\subsubsection{Approach to Animation-Motivations, Objectives, Building Relationships with the Surrounding}

One year after the association was founded in 2016, the identified deficits in sustainable development made the association set the following as a priority of its activity: increasing the civil activity of the town dwellers. However, looking at the diagnosis of the association members, animation should be prioritised in the deprived areas, but should simultaneously focus on those aspects where dwellers' expectations are clearly visible, comprising the history and tradition of the town and the region, as well as maintaining and fostering cultural heritage, including memory about ancestors and genealogy.

The approach to animation is also visible in the attitude of the association leaders: their continual work, discovering talents of particular individuals and social groups, as well as fulfilling the function named by one of the leaders as a herder and a shepherd dog [A2-I1]. Additionally, it is important for the animation activities of the association to remain convinced that development is what people do and not what is done for them [A2-I1].

The most important of the animation processes for the association were the relationships and networks, which made it possible to co-create the additional values for the town community. Building networks started from the interpersonal relationships of the association members derived from their professional activities, as the main leaders of the organisation work at the town hall and in the town culture centre. Another important aspect was communication and cooperation with the town authorities, particularly the mayor and the councilmen. Initially, they dismissed some of the animation ideas or reacted unwillingly, but over time this gradually changed. This was similar for cooperation with the artists in the animation projects, which also followed slowly and arduously.

The association was established for better cooperation with the local community. Its two leaders also work at the town hall, but they perform animation activities within NGOs: I combine the two roles. And even with a friend who is a culture animator ... we talked about organising some workshops as he can see in the whole Poland that there are more such people who work in a public office, and - by playing such a double role-go beyond this role of an officer [A2-I1].

Building both individual and institutional networks, creating cooperation, putting emphasis on joint values, and undertaking activities important for the whole community forms the essence of how the association operates. It happens through projects (including the animating ones) and constant organisational activity.

\subsubsection{Animation Projects}

The association's activity is based on two pillars: the project-oriented and the permanent one. Projects are prepared regularly: We do not search for ideas how to do something that would help us meet the guidelines of a competition. No, we simply search for a competition that would match what we are planning to do [A2-I1]. According to the leaders, they enable panache in activities, going from makeshift to 
professional actions. The ongoing activity of the association includes two complementary ventures realised in cycles from 2016, aimed at discovering and preserving the local heritage. As such, they are related to the popularisation of culture and cultural education. The projects in turn are supposed to concentrate on cultural and social animation: Only in 2017 did we process 100 thousand zloty and this was really a lot. All projects were realised in bulk, it was an enormous workload-projects concerning history, those for seniors, those aimed at boosting civil activity, or artistic ones [A2-F1].

The association realised the following animation tasks as part of consecutive projects: the Senior Council was established as part of the "60+ Council Milestone", wherein a number of actions were realised in the form of intersectoral and intergenerational cooperation, aimed at increasing civil activities and awareness among people over 60 years old living in the town, increasing their potential and social competencies, and strengthening their role in the local community. Next, under the aegis of the Senior Council, the artistic and social activities of the seniors living in this county and the town were initiated and supported. Thereafter, as part of the project, a pilot programme comprising various activities free of charge was prepared in order to support seniors in treatment/rehabilitation, help them improve their physical condition and wellbeing, and gain new interests, skills or contacts, for example at ceramics workshops or trips aimed at learning more about nature or film [A2-O2].

\subsubsection{Continuity of Actions}

The leaders of the association draw attention to the fact that the projects of the association should be consistent, while project objectives should be frequently evaluated, in order to help set the new ones for the areas identified as deprived in the town.

It is claimed by the association that this continuity can be regarded as strategic. Despite the short duration of the organisation (less than five years from the original initiative, and four years from the formal registration), the association has already realised six animation projects dedicated to the dwellers of this town: I can in all honesty say that they are strategic as they are thoughtful, supposed to serve some purpose, and continued, without being random. It is not about someone launching some competition so we decide to do something because we are looking for an idea to meet the requirements of the competition. No, we simply search for a competition that would match what we are planning to do [A2-I2].

According to the leaders of the association, the results of their activities are already visible. First and foremost, new activities occurred which are not directly related to the association, but are part of the social landscape of the town. New local leaders, and new activities and ideas for the town's development related to the activities of the association, but not linked to them in terms of organisation, have emerged. The animation projects of the association "woke people up", and encouraged those who were not actively involved as yet, but had a keen interest in the development of their local community: That's really a lot and these are all bottom-up initiatives. These things are organised by the inhabitants. New associations are established. [ ... . more and more off-stream things are happening that do not attract masses of people but activate groups. [A2-F2]. It is also visible how strongly involved and activated women are: Incredible, wise, active and eager, simply involved; in general, it is obvious that there are different stories here but as a rule it is an unbelievable force. [A2-F1].

Moreover, professionally realised projects emerged in the town. Whenever an idea occurs, external funds are acquired for its realisation and it is then managed according to the adopted methodologies: And we managed to do it properly, from the blueprint to settlement, with all this project cycle, not randomly, it was all planned, there were schedules, invitations, notifications, everything as if there was some standard [A2-I1].

\section{Discussion}

Having described individual case studies, we would like to go on to present and discuss the results of the analysis carried out. We would like to show the dependencies between the specifics of project work and cultural animation. This way of looking at the problem stems from the future-oriented idea of sustainable development, and hence requires also a new look at the projects and their limitations, as well as the unobvious assets. 


\subsection{Animating for Change and Conscious Community}

In the introduction it was emphasised that social and cultural animation is a reaction to the current problems. This is due to the original meaning of animation, from the Latin animatio, that is, stimulation to activity in a given domain, giving impulse to action and simultaneously endeavouring to make the activity more sustainable. Such a way of thinking about animation was visible in both cases we studied. Performing animation activities at a given moment constitutes the initial stage of designing the future, and hence, sustainable development. It is about aiming at agency, which in the long run means encouraging individuals to take over responsibility and building a community in which the productive effects of synergy occur. The Animation 1 case showed that at the local level, animation efforts can be part of a wider strategy of activities for communities, and constitute one element of a political, administrative and social patchwork. According to us, this approach is of "inductive character" — various activities are realised and some of them take the form of animation. It is of paramount value to implement certain solutions top-down, which does not need to involve the organisation managing a given animation project. The Animation 2 case can be regarded as a "deductive" example_the project animation activities constitute a basis for the functioning of the organisation, so they are important not only for the external environment (the recipients of the projects), but also for the internal one (the employees involved in the animation of the organisation).

Dependencies between numerous projects organised in the past or currently, or only planned, affect the dynamics of the development of the organisation. In both cases, projects constitute a reason to build a network that would form the foundation of the sustainable development of both the organisation and the social groups that are linked by a given problem that the animation activity is supposed to make evident or solve. This network, which could also be understood as a community aware of the need for change and the necessity to undertake actions aimed at designing a better future, consists of various people and subjects, including the organisations co-creating and cooperating in consecutive projects, members of the local community involved, sponsors, funders, and politicians creating the local development strategies. At the local level, activities of inductive and deductive character are important, and bring the impulse for change. However, according to the sense of animation, they do not have to lead to measurable effects. Animation oriented towards the process rather than the effects of cultural activities (the meeting itself, during which someone will reach for a brush or scissors) is the most important, more so than whether something will come out of it. Dorota Reksnis adds that "in animation it is the unfinished, the ugly, the nondurable, the unmeaningful that is the most important" [93]. What matters is boosting curiosity, creating conditions for developing creative imagination. Animation understood this way is an investment in the future, and hence an illustration of the assumptions of public policies. Nevertheless, it is not always possible to maintain the integrated positive effect of the projects undertaken. The example of Animation 1 showed that experiences collected from the project do not always bring the development of a given place, which sometimes gets lost due to a lack of continuity between decision-makers. Still, it was the network of the people participating in the project that contributed to building more projects. In this way, Animation 1 showed that sustainable development attempted as a result of animation projects may have a heterogeneous nature, and may surprise even those who designed the projects before they were implemented. It constitutes an interface with the idea of sustainable development. Despite its symbolic meaning, it also has a rational aspect: the future cannot be predicted, but we can encourage someone to feel responsible for it and see their driving force, even without the organisation's continuation.

\subsection{Organisational Paradox: The Short Duration of Projects as Foundation of Sustainable Development}

The problem selected for analysis herein should be perceived in an affirmative way, and focus on the positive features of projects, rather than on criticism arising mostly from massification and the short duration of projects [21,94]. The example of Animation 1 has shown that the project realised opened new possibilities with additional participants. The original activity aimed at destigmatisation developed over time, as well as fighting with social exclusion, and the integration of children and 
youth through culture. On the other hand, the example of Animation 2 showed that sustainable development realised through projects is mainly possible owing to orientation towards individuals and the acquisition thereof. Based on the assumptions of the association activity (Animation 2), projects make sense if they concentrate on what people do and not what is imposed on them. This means that projects are processes initiating a symbolic opening up of communities to new impulses and perspectives. Hence, the formal features of projects, comprising the moments of starting and finishing, and the evaluation of the results achieved are only conventional, and do not constitute the essence of the activity—both for their organisers and recipients.

A different trend can be observed, whereby projects create a particular ecosystem which helps in developing the awareness of their participant, which is difficult to measure. Their educational value does not need to be translated into concrete results, as animators are much more interested in acquisition. Therefore, many small projects, which obviously dominate in the example of Animation 2, contribute to the gradual but consistent and permanent creation of conditions for sustainable development. The example of Animation 1 showed, in turn, the value of experience in project management gained by the individuals creating the network of project participants and local stakeholders. Projects may be "impulses", or short incentives, while the network built of their results is in this sense of a permanent nature. Thus, projects are an example of animation towards sustainable development through the creation of appropriate organisational structures, as well as the collecting of experiences. Additionally, projects are an interesting form of animation at the local level, often not only conducted by well-educated animators but also co-created by the communities themselves. Although according to contemporary project practices the range of projects is wide, sometimes taking the form of megaprojects [95], at the micro-level their meaning can easily be followed to implement certain ideas and create changes important for a community, not because of their prestige or panache, but because of their meaning. Simultaneously, the projectification of culture and its funding makes it necessary to adapt project formats, but does not exclude a flexible and creative approach to them, which is visible in the examples analysed. Animation projects can be regarded as an adaptation strategy on the formal level, yet in terms of content they do not have to be limiting, as is often presented as an argument in criticism thereof. We see in it an organisational paradox: an affirmative use of projects to create sustainability through their ephemeral character.

\subsection{Cultural Animation in Organisations Versus the Process of Projectification}

In order to make it possible to create added value in the context of sustainable development, it is necessary to learn about the features of projects and animation which might at first glance seem mutually exclusive, but that contain many common features, particularly those related to designing the future through action. The most important features are included in Table 2 below.

Table 2. Features characteristic of projects and cultural animation.

\begin{tabular}{cc}
\hline Projects & Animation \\
\hline $\begin{array}{c}\text { Defining at the beginning the parameters and } \\
\text { resources: schedule, objectives, budget, involvement } \\
\text { of certain people and resources }\end{array}$ & $\begin{array}{c}\text { No preliminary assumptions, including defined } \\
\text { objectives. }\end{array}$ \\
\hline Clearly defined objectives & $\begin{array}{c}\text { The objective beyond the animator's decision and } \\
\text { dependent on the reaction of recipients }\end{array}$ \\
\hline Attempts to design the effect & Deferred effect \\
\hline Of institutional origin & Dedicated to a specific community \\
\hline $\begin{array}{c}\text { Future-oriented } \\
\text { Pursuing realisation of new projects after finishing } \\
\text { one }\end{array}$ & $\begin{array}{c}\text { Future-oriented } \\
\text { Concentration on a given activity irrespective of its } \\
\text { duration }\end{array}$ \\
\hline
\end{tabular}


The basic common feature combining animation and projects is orientation towards activity, as well as taking actions and change, which all influence the future. As already indicated, this interface is important for sustainable development. However, one needs to be aware of essential differences: the aiming at organisational precision and order, the defining of activities and results for projects, as well as the degree of spontaneity and openness to the unplanned effects of animation. Based on our research, we assume that combining these two factors creates an interesting framework for the achievement of sustainable development, where the elements of organisational order and methodical activity meet originality and creativeness. Projects could be understood as practical tools of animation, used to initiate changes with a sustainable result, and animation could be understood as an idea realised with the use of the project methodology. Simultaneously, it is crucial for this idea to last after the formal finalisation of the project, which draws attention to the phenomena resulting from the popularity of project-based work. In our opinion, the most important phenomenon is projectification, the currently ongoing process of increasing quality and quantity. On one hand, there are more and more projects, and on the other, their significance in work management and the understanding of the ways of defining work in modern society is growing [96,97]. In the area of culture, including social and cultural animation, many factors are conducive to project work. This concerns the need for change in the modern society [98], employment uncertainty, difficulties in planning [99], insufficient financing, and the necessity of searching for various sources of support [21]. Projects are often regarded as a remedy to organisational difficulties. However, they only serve a temporary intervention, after which problems come back, the reaction to which is usually another project. This is visible in the example of Animation 2, in which attempts are made to make the effects durable. In Poland, but also in other countries of the European Union, organising cultural activity is based on a strong project foundation, which stems from the numerous possibilities of financing projects from grants. There are currently no alternatives to projects, and contesting them as the form of resistance to external pressure and expectations regarding adjustments might only mean professional oblivion [21]. It is also worth noticing that the public funding of cultural institutions often gives them only the possibility to "last" and cover the current expenses, including remuneration of its employees, rather than realise their artistic programme. It should also be emphasised that projectification of culture not only cements the existence of NGOs as complementary to the institutional landscape, but also leads to new organisation formats. Employees of the cultural sector cooperate for a certain time in teams, which are usually added to the permanent structures of the institutions officially responsible for a given project, or they change the organisations for every new project (as shown in the example of Animation 1). Various types of temporary organisations are established within projects: creative communities, strategic partnerships with sponsors, networks, groups of specialists in writing project applications, etc. This boosts projectification processes and "project automatism", for example in the entities like the one described in Animation 2. Simultaneously, as stated in the previous point, aiming at the durability of results can paradoxically be regarded as the first signal of conscious functioning in the external environment of the organisation. This is because, following the assumptions of sustainable development, it is not about reproducing one after another project, but creating a social value expressed in the feeling of agency, which will secure long-term development aimed at co-shaping a good future (Animation 1). This idea can be treated as a gap in project research. In this context, the examples described herein constitute a pioneering approach: animation, based on project foundations, aimed at sustainable development and the developing of management models on a local level, which are future-oriented even beyond the borders of one certain organisation that is initiating, for various reasons, a given action.

\section{Conclusions}

In answering the first of the research questions (How is cultural animation aimed at sustainable development carried out in local communities?), we suggest the following: for the organisations, the studied animation is about providing initial organisational conditions for the creation of a new 
social reality, while simultaneously imparting on the participants the tools to maintain the new state of affairs. Based the accessibility of funds and the specific expectations of the financing institutions related to the supervision of public funds, who exhibit control and an eagerness to monitor results, the form of the project, which brings a framework to the animation activities, is usually selected. The approaches to cultural animation aiming at sustainable development are different in the studied cases. A public organisation realises activities based on the formally defined strategic objectives of a town or city. In other words, animation fits in with the previously determined frameworks and objectives stemming from the policy of municipal authorities towards sustainable development. An NGO in turn directs its animating activity towards gaps identified in the activity of public organisations, and constitutes alternative activities for the sustainable development strategy of a town or city.

In answering the second of the research questions (What is the influence of project-based animation activities on sustainable development, and how do they contribute to building a sustainable ecosystem at the local level?), it needs to be emphasised that the examples described show that achieving durable results and creating foundations of sustainable development depends on what relationships, during the realisation of particular projects, are possible, and whether networks linking various stakeholders (public and non-government entities, individuals, communities and groups) will be established. One needs to also regard the community built around a given activity as an ecosystem, which can have a more symbolic character than the network emerging and maintained in order to conduct the organisational activities, and as something that remains after the activity's completion. Simultaneously, it needs to be emphasised that in this type of organisational ecosystem, all parties involved influence each other. Both project frameworks and animating activities contain an encoded element of each participant's activity. The sum of these activities is based on interactions between individuals and groups. Moreover, it needs to be emphasised that when realising projects, one needs to be aware of the negative and positive aspects. Although projects are based on parameters agreed on at the beginning (duration, results, resources engaged), they guarantee flexibility of action if they are perceived as processes related to a change in the future that exceeds the formal finalisation of a project. When answering the third research question (How does the relation between project and cultural animation aimed at sustainable development look in practice?), we focused on the relationships between projects and cultural animation. Both cases analysed showed that, despite organisational differences and a different level of identification in the recipients of the actions (higher for Animation 2 than for Animation 1 , stemming from the bottom-up initiatives of the association, instead of a public organisation providing its own solutions), the form of the project fits animation understood as an initiation of the process of change. An important aspect constituting part of both projects and animations is the topic of changing and designing the future, which can in turn lead to sustainable development.

By examining the implementation of the concept of sustainable development through cultural animation at the local level, the overall aim of the paper is to increase the understanding of the role of cultural animation in sustainable development. The project practices undertaken by the studied organisations in the area of cultural animation showed that the means and the scope of the realisation of cultural animation activities at the local level are determined by many factors, including the specifics of the local environment, its needs, as well as resources available for the organisations and the networks they co-create. Of particular importance, as proven in practice, are the financial resources that organisations have at their disposal or are able to acquire for particular ventures. Organisations responsible for public policies, and the funds allocated within these policies, set concrete objectives, for which the financial means must be assessed. This often makes organisations realise cultural animation ventures in order to maintain continuity of the activities dedicated to local communities, and therefore they fall into the trap of projectification $[21,100]$. Project becomes a remedy to local problems. This stems from haste, and a lack of understanding of projects as organisational formats not only of qualitative but also quantitative character. Therefore, in order to create the future of cultural initiatives, including animations according to the idea of sustainable development, one needs to search for the more subtle elements of project work, exceeding the traditional understandings of these as time-limited 
one-off actions aimed at a certain objective. Animation is an open-ended action, with ephemeral results which may occur years after projects are finished. Thus, sustainable development based on cultural activities cannot be designed but triggered, which means that an impulse is given and processes are set into motion, bringing unique experiences for the people involved in different roles. This is of particular importance for non-government organisations, as opposed to public organisations, which have to search for sources of finance for their activities. Additionally, projects allow organisations (particularly from the public sector) to go beyond their regular scheme of activities, and extend the existing offer. Such an approach to projects makes them a tool used to realise activities in the area of cultural animation, and also, more broadly in sustainable development.

Answering the question of which approach is worth pursuing in further in-depth research concerns the durability of the changes and processes initiated by the studied projects. As shown by the experience of the cases described, and wider considerations concerning managing social problems [101], the implementation and popularisation of ventures realised via animation methods depends on many conditions which are not separable but complementary to each other, and sometimes overlap, strengthening their impact. The most important are the institutional environment (including the institutions realising the activities), the approach of the local authorities, and the building of a community around the results of the actions taken. Last but not least, a conscious approach to project work is important, bringing value to every single activity rather than a project mass in which the need for future-oriented thinking gets lost.

Author Contributions: Conceptualisation: M.Ć., A.G. and E.B.-W.; methodology: E.B.-W.; validation: M.Ć., A.G., E.B.-W.; formal analysis: M.Ć., A.G.; investigation: M.D., E.B.-W.; resources: M.D., E.B.-W.; data curation: M.Ć., A.G., E.B.-W.; writing—original draft preparation: M.Ć., A.G., E.B.-W.; writing—review and editing: M.Ć., A.G., E.B.-W. All authors have read and agreed to the published version of the manuscript.

Funding: This research received no external funding.

Conflicts of Interest: The authors declare no conflict of interest.

\section{References}

1. Nurse, K. Culture as the Fourth Pillar of Sustainable Development. 2006. Available online: https://pdfs.semanticscholar.org/6fff/5b882d7a57a79e6aecc651db99a3cc290cbe.pdf?_ga=2.258854284. 700605224.1587715109-892364528.1587715109 (accessed on 30 January 2020).

2. Stephenson, J. The cultural values model: An integrated approach to values in landscapes. Landsc. Urban Plan. 2007, 84, 127-139. [CrossRef]

3. Throsby, D. Economics and Culture; Cambridge University Press: Cambridge, UK, 2001.

4. Trimarchi, M. Regulation, integration and sustainability in the cultural sector. Int. J. Herit. Stud. 2004, 19, 410-415. [CrossRef]

5. Smith, L. Uses of Heritage; Routledge: London, UK, 2006.

6. Holden, J. The Ecology of Culture. Available online: http://www.ahrc.ac.uk/News-and-Events/News/ Documents/AHRC\%20Ecology\%20of\%20Culture\%20\%28A\%29.pdf (accessed on 15 March 2020).

7. World Commission on Environment and Development. Our Common Future. (The Brundtland Report); Oxford University Press: Oxford, UK, 1987.

8. Spencer-Oatey, H. Culturally speaking. In Culture, Communication and Politeness Theory, 2nd ed.; Continuum: London, UK, 2008.

9. Isar, Y. 'Culture', 'sustainable development' and cultural policy: A contrarian view. Int. J. Cult. Policy 2017, 23, 148-158. [CrossRef]

10. Birkeland, I. Cultural sustainability: Industrialism, placelessness and the reanimation of place. Ethics Place Environ. 2008, 11, 283-297. [CrossRef]

11. Wijngaarden, Y.; Hitters, E.; Bhansing, P.V. Close to the 'local cool': Creative place reputation in Dutch 'ordinary cities'. Creat. Ind. J. 2019, 12,1-20. [CrossRef] 
12. Yigitcanlar, T.; Guaralda, M.; Taboada, M.; Pancholi, S. Place Making for Knowledge Generation and Innovation: Planning and Branding Brisbane's Knowledge Community Precincts. J. Urban Technol. 2016, 23, 115-146. [CrossRef]

13. Stylianou-Lambert, T.; Boukas, N.; Christodoulou-Yerali, M. Museums and cultural sustainability: Stakeholders, forces, and cultural policies. Int. J. Cult. Policy 2014, 20, 566-587. [CrossRef]

14. Loach, K.; Rowley, J.; Griffiths, J. Cultural sustainability as a strategy for the survival of museums and libraries. Int. J. Cult. Policy 2017, 23, 186-198. [CrossRef]

15. Moldavanova, A. Two narratives of intergenerational sustainability: A framework for sustainable thinking. Am. Rev. Public Adm. 2016, 46, 526-545. [CrossRef]

16. Pop, I.; Borza, A.; Buiga, A.; Ighian, D.; Toader, R. Achieving Cultural Sustainability in Museums: A Step Toward Sustainable Development. Sustainability 2019, 11, 970. [CrossRef]

17. Lee, T.H.; Jan, F.H. Can community-based tourism contribute to sustainable development? Evidence from residents' perceptions of the sustainability. Tour. Manag. 2019, 70, 368-380. [CrossRef]

18. Trilla, J. Conceito, exame e universo da animação sociocultural. In Animação Sociocultural: Teorias, Programas e Âmbitos; Trilla, J., Ed.; Instituto Piaget: Lisboa, Portugal, 2004; pp. 19-43.

19. Kelemen, M.; Hamilton, L. The Role of Creative Methods in Redefining the Impact Agenda, CASIC Working Papers Series. 2015. CWPS0001. Available online: https://www.keele.ac.uk/casic/workingpaperseries/ (accessed on 30 January 2020).

20. Heerkens, G. Jak Zarzadzać Projektami; Wydawnictwo RM: Warszawa, Poland, 2003.

21. Szreder, K. ABC Projektariatu; Bęc Zmiana: Warszawa, Poland, 2016.

22. Hodgson, D.; Cicmil, S. (Eds.) Making Projects Critical; Palgrave Macmillan: New York, NY, USA, 2006.

23. Baur, N.; Besio, C.; Norkus, M. Projectification of science as an organizational innovation. In Innovation Society Today; Rammert, W., Windeler, A., Knoblauch, H., Hutter, M., Eds.; Springer VS: Wiesbaden, Germany, 2017; pp. 341-370.

24. Soini, K.; Birkeland, I. Exploring the scientific discourse on cultural sustainability. Geoforum 2014, 51, $213-223$. [CrossRef]

25. Carley, M.; Christie, I. Managing Sustainable Development; Earthscan: London, UK, 2000.

26. Petschow, U.; Rosenau, J.; Von Weizsacker, E. Governance and Sustainability: New Challenges for States, Companies and Civil Society; Greenleaf: Sheffield, UK, 2005.

27. Loorbach, D. Transition Management for Sustainable Development: A Prescriptive, Complexity-Based Governance Framework. Governance 2010, 3, 161-183. [CrossRef]

28. Waas, T.; Hugé, J.; Block, T.; Wright, T.; Benitez-Capistros, F.; Verbruggen, A. Sustainability Assessment and Indicators: Tools in a Decision-Making Strategy for Sustainable Development. Sustainability 2014, 6, 5512-5534. [CrossRef]

29. Karborm Gustavsson, T.; Hallin, A. Goal seeking and goal oriented projects-Trajectories of the temporary organization. Int. J. Manag. Proj. Bus. 2015, 8, 368-378. [CrossRef]

30. Swanson, K.K.; DeVereaux, C. A theoretical framework for sustaining culture: Culturally sustainable entrepreneurship. Ann. Tour. Res. 2017, 62, 78-88. [CrossRef]

31. World Commission on Culture and Development. In Proceedings of the UNESCO General Conference, 27th Session, Paris, France, 25 October-16 November 1993. Available online: https://unesdoc.unesco.org/ark: /48223/pf0000095724 (accessed on 30 January 2020).

32. European Task Force on Culture and Development. From the Margins: A Contribution to the Debate on Culture and Development; Council of Europe: Strasbourg, France, 1997.

33. Soini, K.; Dessein, J. Culture-sustainability relation: Towards a conceptual framework. Sustainability 2016, 8, 167. [CrossRef]

34. Hawkes, J. The Fourth Pillar of Sustainability: Culture's Essential Role in Public Planning; Common Ground P/L: Melbourne, Australia, 2001.

35. Mpofu, P. The dearth of culture in sustainable development: The impact of NGOs' agenda and conditionalities on cultural sustainability in Zimbabwe. J. Sustain. Dev. Afr. 2012, 14, 191-205.

36. Chiu, R. Socio-cultural sustainability of housing: A conceptual exploration. Hous. Theory Soc. 2004, 21, 65-76. [CrossRef]

37. Asikainen, S.; Brites, C.; Plebanczyk, K.; Rogac Mijatovic, K.; Soini, K. (Eds.) Culture in Sustainability: Towards a Transdisciplinary Approach; Jyväskylä University: Jyväskylä, Finland, 2017. 
38. Hristova, S.; Dragicevic Sesic, M.; Duxbury, N. Culture and Sustainable Development in European Cities: Imagining Europolis; Routledge: London, UK, 2015.

39. Pereira, H.N. Contemporary trends in conservation: Culturalization, significance and sustainability. City Time 2007, 3, 15-25.

40. Bengtsson, S.L.; Östman, L.O. Globalisation and education for sustainable development: Emancipation from context and meaning. Environ. Educ. Res. 2013, 19, 477-498. [CrossRef]

41. Throsby, D. Linking ecological and cultural sustainability. Int. J. Divers. Organ. Commun. Nations 2008, 8, 15-20. [CrossRef]

42. Duxbury, N.; Gillette, E. Culture as a Key Dimension of Sustainability. Exploring Concepts, Themes, and Models; Working Paper 1; Creative City Network of Canada, Centre of Expertise on Culture and Communities: Vancouver, BC, Canada, 2007; pp. 1-23.

43. Kelemen, M.; Phillips, M.; Moffat, S.; James, D. Performing the legacy of animative and iterative approaches to co-producing knowledge. In Valuing Interdisciplinary Collaborative Research: Beyond Impact; Facer, K., Pahl, K., Eds.; Policy Press: Bristol, UK, 2017; pp. 107-130.

44. Kalcheva, A. Theoretical and historical aspects of socio-cultural animation. Trakia J. Sci. 2016, 3, $203-206$. [CrossRef]

45. James, D. Evaluating the Legacy of Animative and Iterative Connected Communities Projects: Reflections on Methodological Legacies. 2015. Available online: https://www.keele.ac.uk/media/keeleuniversity/ri/risocsci/ thelegacyofconnectedcommunities/FINAL\%20EVALUATING\%20LEGACY\%20REPORT\%20NCVO\% 20300915\%20(1).pdf (accessed on 30 January 2020).

46. Kargul, J. Od Upowszechniania Kultury do Animacji Kulturalnej; Wydawnictwo Adam Marszałek: Torun, Poland, 1997.

47. Kaczmarek, U. Animacja społeczno-kulturalna. In Organizacja i Upowszechnianie Kultury w Polsce. Zmiany Modelu; Grad, J., Kaczmarek, U., Eds.; Wydawnictwo Naukowe UAM: Poznań, Poland, 1999; pp. 118-119.

48. Montez, M. Sociocultural Animation and Community Development-Contributions for Social Work. 2018. Available online: https://www.researchgate.net/publication/332470056_Sociocultural_Animation_and_ Community_Development_-contributions_for_social_work (accessed on 9 July 2020).

49. Gillet, J.-C. Animation et Animateurs: Le Sens de l'action; L'Harmatan: Paris, France, 1995.

50. Council of Europe. Socio-Cultural Animation; Council of Cultural Cooperation: Strasbourg, France, 1978.

51. Ander-Egg, E. La Problemática de l'Animación Sociocultural; San Pablo: Buenos Aires, Argentina, 2012; pp. $24-38$.

52. Goldbard, A. New Creative Community: The Art of Cultural Development; New Village Press: New York, NY, USA, 2006.

53. Morawska, I.; Latoch-Zielińska, M. Animacja kulturalna kluczem do uczestnictwa w kulturze. In Animacja Działań Kulturalnych—Wyzwanie Wspótczesności; Białkowski, A., Ed.; Fundacja Muzyka jest dla Wszystkich: Warszawa, Poland, 2010; pp. 11-29.

54. Fatyga, B. Poza instytucjonalne i nieformalne uczestnictwo w kulturze. Trzeci Sektor 2009, 19, 14-19.

55. Diamond, L. Rethinking Civil Society: Toward Democratic Consolidation. J. Democr. 1994, 5, 4-17. [CrossRef]

56. Warkentin, C.; Mingst, K. International Institutions, the State, and Global Civil Society in the Age of the World Wide Web. Glob. Gov. 2000, 6, 237-257. [CrossRef]

57. Siciński, A. O idei społeczeństwa obywatelskiego. Wiedza I Życie 1996, 6, 28.

58. Berger, P.R.; Neuhaus, R.J. To Empower People: The Role of Mediating Structures in Public Policy; American Enterprise Institute for Public Policy Research: Washington, DC, USA, 1977.

59. Mencwel, A. Przyczyniać się pomału. In Animacja Kultury. Doświadczenie i Przyszłość; Godlewski, G., Kurz, I., Mencwel, A., Wojtowski, M., Eds.; Instytut Kultury Polskiej UW: Warszawa, Poland, 2002; pp. 13-26.

60. Gauntlett, D. Creative Explorations: New Approaches to Identities and Audiences; Routledge: London, UK, 2007.

61. Robert, K. Tools and concepts for sustainable development, how do they relate to a general framework for sustainable development, and to each other? J. Clean. Prod. 2000, 8, 243-254. [CrossRef]

62. Garel, G. A history of project management models: From pre-models to the standard models. Int. J. Proj. Manag. 2013, 31, 663-669. [CrossRef]

63. Trocki, M.; Grucza, B.; Ogonek, K. Zarzadzanie Projektami; Wydawnictwo Ekonomiczne: Warszawa, Poland, 2003. 
64. Golini, R.; Kalchschmidt, M.; Landoni, P. Adoption of project management practices: The impact on international development projects of non-governmental organizations. Int. J. Proj. Manag. 2015, 33, 650-663. [CrossRef]

65. Turner, J.R.; Huemann, M.; Anbari, F.; Bredillet, C. Perspectives on Projects; Routledge: London, UK, 2010.

66. Lundin, R.; Arvidsson, N.; Brady, T.; Ekstedt, E.; Midler, C.; Sydow, J. Managing and Working in Project Society: Institutional Challenges of Temporary Organizations; Cambridge University Press: Cambridge, UK, 2015.

67. Jensen, A.; Thuesen, C.; Geraldi, J. The projectification of everything: Projects as a human condition. Proj. Manag. J. 2016, 47, 21-34. [CrossRef]

68. Ćwikła, M. Projekt to Jest Projekt. Specyfika Zarzadzania Projektami Kulturalnymi na Przykładzie Tworzenia Koprodukcji Teatralnych; Attyka: Kraków, Poland, 2016.

69. Büttner, S.; Leopold, L. A 'new spirit' of public policy? The project world of EU funding. Eur. J. Cult. Political Sociol. 2016, 3, 41-71. [CrossRef]

70. Gareis, R.; Huemann, M.; Martinuzzi, A. Project Management and Sustainable Development Principles; Project Management Institute: Newtown Square, PA, USA, 2013.

71. Svejvig, P.; Andersen, P. Rethinking project management: A structured literature review with a critical look at the brave new world. Int. J. Proj. Manag. 2015, 33, 278-290. [CrossRef]

72. Palm, K.; Lindahl, M. A project as a workplace: Observations from project managers in four R\&D and project-intensive companies. Int. J. Proj. Manag. 2015, 33, 828-838.

73. Kallis, G.; Kerschner, C.; Martinez-Alier, J. The economics of degrowth. Ecol. Econ. 2012, 84, 172-180. [CrossRef]

74. Porter, M.E.; Kramer, M.R. Creating shared value. Harv. Bus. Rev. 2011, 89, 62-77.

75. Eskerod, P.; Huemann, M. Sustainable development and project stakeholder management: What standards say. Int. J. Manag. Proj. Bus. 2013, 6, 36-50. [CrossRef]

76. Matarasso, F.; Landry, C. Balancing act: Twenty-one strategic dilemmas in cultural policy. In Cultural Policies Research and Development Unit Policy Note No. 4; Council of Europe Publishing: Strasbourg, France, 1999.

77. Zbudilová, H. Socio-Cultural Animation in Spain and Latin America-A historical overview. Pedagog. Orientace 2017, 27, 40-557. [CrossRef]

78. Mills, A.J.; Durepos, G.; Wiebe, E. (Eds.) Encyclopedia of Case Study Research, Volumes I and II; Sage: Thousand Oaks, CA, USA, 2010.

79. Yin, R.K. Case Study Research. Design and Method, 2nd ed.; The Sage Publications: Thousand Oaks, CA, USA, 1994.

80. Stake, R.E. Qualitative case studies. In Qualitative Research, 3rd ed.; The Sage Publications: Thousand Oaks, CA, USA, 2005; pp. 443-467.

81. Lofland, J.; Snow, D.; Anderson, L.; Lofland, L. Analyzing Social Settings: A Guide to Qualitative Observation and Analysis; Thomson Learning, Inc.: Wadsworth, OH, USA, 2006.

82. Gray, D. Doing Research in the Real World, 2nd ed.; The Sage Publications: Thousand Oaks, CA, USA, 2009.

83. Starman, A.B. The case study as a type of qualitative research. J. Contemp. Educ. Stud. 2013, 1, $28-43$.

84. Holstein, J.A.; Gubrium, J.F. Interpretative practice and social action. In The Sage Handbook of Qualitative Research; Denzin, N.K., Lincoln, Y.S., Eds.; The Sage Publications: London, UK; Los Angeles, CA, USA; New Delhi, India; Singapore; Washington, DC, USA, 2005.

85. Burrel, G.; Morgan, G. Sociological paradigms and organisational analysis. In Elements of the Sociology of Corporate Life; Ashgate Publishing Company: Burlington, VT, USA, 1979.

86. Weick, K. Sensemaking in Organizations; SAGE Publications: Thousand Oaks, CA, USA, 1995.

87. Berger, P.L.; Luckmann, T. The social construction of reality. In A Treatise in the Sociology of Knowledge; Penguin Books: London, UK, 1991.

88. Sułkowski, Ł. Epistemologia i Metodologia Zarzadzania; Polskie Wydawnictwo Ekonomiczne: Warszawa, Poland, 2012.

89. Creswell, J. Research Design: Qualitative, Quantitative, and Mixed METHODS Approaches, 3rd ed.; The Sage Publications: Thousand Oaks, CA, USA, 2009.

90. Flick, U. Managing Quality in Qualitative Research; Sage Publications Inc: Thousand Oaks, CA, USA, 2007.

91. Denzin, N.K. The Research Act, 3rd ed.; Prentice Hall: Englewood Cliffs, NJ, USA, 1989.

92. Fatyga, B. Żywa Kultura. Available online: http://ozkultura.pl/node/112 (accessed on 30 March 2020). 
93. Reksnis, D. Idee/Ideas: Sztuka/Art. In Teraz! Animacja Kultury/Culture Animation Now! Stowarzyszenie Katedra Kultury: Warszawa, Poland, 2008.

94. Groys, B. Going Public; Sternberg Press: Berlin, Germany, 2010.

95. Flyvbjerg, B. What You Should Know about Megaprojects and why: An Overview. Proj. Manag. J. 2014, 45, 6-19. [CrossRef]

96. Midler, C. Projectifcation of the Firm: The Renault Case. Scand. J. Manag. 1995, 11, 363-375. [CrossRef]

97. Packendorff, J.; Lindgren, M. Projectification and its consequences: Narrow and broad conceptualisations. S. Afr. J. Econ. Manag. Sci. 2014, 17, 7-21. [CrossRef]

98. Bauman, Z. Times of Interregnum. Ethics Glob. Politics 2012, 5, 49-56. [CrossRef]

99. Rosa, H. Beschleunigung. In Die Veränderung der Zeitstrukturen in der Moderne; Suhrkamp: Frankfurt am Main, Germany, 2005.

100. Ćwikła, M.; Jałocha, B. Unspread Wing: Why Cultural Projects don't Provide Refreshing Ideas for Project Management although They Could? Int. J. Manag. Proj. Bus. 2015, 8, 626-648. [CrossRef]

101. Jones, T.; Donaldson, T.; Freeman, R.; Harrison, J.; Carrie, R.; Leana, C.; Mahoney, J.; Pearce, J. Introduction to Special Topic Forum Management Theory and Social Welfare: Contributions And Challenges. Acad. Manag. Rev. 2016, 41, 216-228. [CrossRef]

(C) 2020 by the authors. Licensee MDPI, Basel, Switzerland. This article is an open access article distributed under the terms and conditions of the Creative Commons Attribution (CC BY) license (http://creativecommons.org/licenses/by/4.0/). 